\title{
RAÇA E CIDADANIA NO PÓS-ABOLIÇÃO MARANHENSE (1888-1889) ${ }^{1}$
}

Matheus Gato ${ }^{2}$

$\mathbf{N}$ o livro de memórias A esfinge do Grajaú (1940), o abolicionista Dunshee de Abranches narra sua viagem rumo aos chamados sertões do Maranhão, para exercer a condição de promotor público, em agosto de 1888. No povoado de Pau d'Arco, próximo à cidade de Pedreiras, na região do Alto Mearim, o jovem funcionário do Estado descobriu que, passados três meses da abolição, "o tambor rufava há duas semanas em honra do Espírito Santo, festejava-se ainda a Lei de 13 de maio. Magotes de libertos, chegados de pontos longínquos, pungavam dia e noite ao som desse batuque infernal, alimentados pelo álcool." ${ }^{3}$ Logo que os libertos souberam tratar com um homem da lei, proveniente da capital, denunciaram que, ali próximo, nas terras do major Saldanha, ex-deputado da Assembleia Provincial, "o bacalhau [chicote] continuava a reinar e os negros a gemerem na escravidão." ${ }^{\circ} \mathrm{O}$ promotor público dirigiu-se à fazenda, a fim de confirmar as acusações:

1 Uma primeira versão deste artigo foi apresentada ao Grupo de Trabalho Sociologia Histórica no $18^{\circ}$ Congresso da Sociedade Brasileira de Sociologia realizado em Brasília no ano de 2018. Agradeço as críticas e comentários dos professores Fernando Salla, Alessandra Teixeira e do parecerista da Afro-Ásia.

2 Faz pós-doutorado em Sociologia pela Universidade de São Paulo. Esta pesquisa é financiada pela Fundação de Amparo à Pesquisa do Estado de São Paulo (Fapesp).matheusgatodejesus@ gmail.com

3 Dunshee de Abranches, A esfinge do Grajaú, São Luís: Alumar, 1993, p. 68.

4 Abranches, A esfinge do Grajaú, p. 68. 
Ao enfrentar a porteira da fazenda do régulo matuto, mandei que o meu companheiro fosse indagar se se achava em casa [o major Saldanha]. Alguns pretos, que acudiram ao tropel dos cavalos, responderam que, três dias antes, seguira para capital. Fiz então uma pequena fala para esses infelizes, que nos confessaram que "seu Senhor disse-lhes que, de fato, haviam sido forros pelo Imperador, mas que tinham que continuar a trabalhar nas roças até que o Governo pagasse suas alforrias". Procurei convencê-los de que estavam sendo ludibriados pelo major, mas, ao meter esporas no cavalo, tive certeza que permaneceriam servilmente no eito. ${ }^{5}$

Esse relato dos rincões maranhenses informa o quanto a construção social da liberdade no Brasil foi um processo diferenciado e desigual. A emancipação dos últimos escravos foi sancionada numa só penada, mas chegou de diversas maneiras ao norte e ao sul do país, conforme: o desenvolvimento da economia e sua função no sistema agroexportador; a preponderância ou não da população negra e mestiça nas províncias, cidades, comarcas e povoados; a importância do trabalhador livre nas diferentes agriculturas escravistas; a presença do incentivo estatal ou privado em favor da imigração estrangeira europeia ou asiática; o atraso ou modernização do sistema produtivo da grande lavoura; a força política do latifúndio no pós-abolição e a relevância dos estados e regiões na condução da política brasileira.

Nesse sentido, a configuração do pós-abolição brasileiro foi um processo heterogêneo. Mesmo nos casos de "continuidade", em que houve a manutenção da escravidão ou da tutela sobre os libertos após o 13 de maio, as condições que viabilizaram a persistência do domínio senhorial variaram em diferentes lugares e situações. Entretanto, não é demasiado lembrar que, para os negros - fossem cativos ou livres -, a abolição foi uma transformação política radical, que afetou profundamente o modo com que eles enxergavam os seus direitos e o seu sentido de pertencimento à nação brasileira. Não sem razão, o tambor rufava em festa no interior maranhense, meses depois de legalizado o fim cativeiro no país, e os libertos não perderam a chance de denunciar a escravização 
ilegal, assim que tiveram oportunidade. Mesmo as pessoas escravizadas pelo major Saldanha sabiam que haviam sido "forras" pelo imperador e, provavelmente, aceitaram sua condição, entre outras razões, devido ao senso comum vigente de que as "alforrias" precisavam ser pagas.

Este artigo visa caracterizar o pós-abolição maranhense, tendo em vista a relação entre a luta social pelos significados da liberdade na derrocada do mundo senhorial e o progressivo estabelecimento da categorização racial enquanto critério hegemônico de subordinação de grupos. Trata-se de investigar as especificidades do processo de racialização numa região periférica do Brasil, observando o modo como as classificações de cor e outras de grupo vigentes na sociedade imperial e escravista brasileira (como "libertos", "moleques", "negrinhas" etc.) se tornaram portadoras das ideias raciais modernas oitocentistas que se disseminaram no país, alimentando um senso comum e prático acerca da inferioridade biológica e cultural dos negros. Um contexto privilegiado para observar a constituição de uma cidadania negra, de segunda classe, no Brasil.

O conceito de racialização foi originalmente cunhado pelo psiquiatra e filósofo Franz Fanon, em Os condenados da Terra ${ }^{6} \mathrm{O}$ autor pretendia demonstrar que não era natural, especialmente nas sociedades ocidentais modernas, que um indivíduo pensasse a si mesmo como "negro" ou "branco", ao invés de reivindicar a universalidade pressuposta na condição humana. Se as raças não eram algo dado, Fanon considerava necessário elucidar os percursos psíquicos e históricos que teriam implicado na formação de subjetividades raciais. Alguns sociólogos aproveitaram a ideia para analisar o desenvolvimento da formação de grupos racializados, em determinados contextos históricos. Os usos do conceito variaram na tradição sociológica. Conforme a importante definição de Robert Miles, podemos entender racialização como "um sinônimo para o conceito de 'categorização racial', definida como um processo de delineamento de fronteiras de grupo e alocação de pessoas dentro dessas fronteiras por uma referência primária a características (supostamente) inerentes e/ou biológicas (usualmente fenotípicas). ${ }^{.7}$ Nesse sentido, uma

6 Franz Fanon, Os condenados da Terra, Juiz de Fora: Editora da UFJF, 2005, p. 246.

7 Robert Miles e Malcolm Brown, Racism, Londres: Routledge, 2003, p. 100 (tradução nossa). 
sociedade pode passar por diferentes processos de racialização em sua história e o conceito não depende, necessariamente, da ideia moderna de raça forjada pelo colonialismo europeu.

Neste artigo, o conceito de racialização é utilizado de duas formas específicas. A primeira para definir a imposição de categorias a um grupo - no caso, os libertos e outros negros. A segunda trata da racialização como a instituição da raça num dos princípios dominantes de hierarquização das pessoas na sociedade brasileira moderna, organizada pelo trabalho livre e instituições republicanas. Trata-se de uma utilização restrita, voltada ao entendimento do racismo moderno, cada vez menos marcado pela herança colonial e pelas antigas crenças místicas e religiosas sobre as cores, que enfoca os processos sociais, políticos e econômicos que permitiram a generalização de percepções e discursos sobre raça. Refere-se, portanto, aos processos que inferiorizam e atribuem essências a grupos sociais, remetendo frequentemente à transmissão de traços fisionômicos e qualidades intelectuais e morais negativas, imaginados como naturais e/ou hereditárias. ${ }^{8}$ Embora meu enfoque se concentre no período imediatamente pós-abolição, contexto a que pertencem os fatos analisados, a vantagem de interpretar o fenômeno da racialização processualmente é observar que a formação de esquemas raciais de percepção estão relacionados com as condições sociais e as experiências de emancipação dos negros que antecederam ao fim da escravidão. O racismo brasileiro moderno não data do dia 13 de maio de 1888, mas das reações nobiliárquicas da elite brasileira às pressões igualitárias, internacionais e nacionais, forjadas ao longo da crise mundial do escravismo no século XIX.

Tal problema impõe perguntas sobre a importância da cor como critério de distinção na estrutura social brasileira, antes da abolição. A questão é relevante porque, no Brasil, o fim da escravidão faz parte do desmantelamento de uma ordem social específica - a sociedade imperial -, em que as distinções entre os grupos sociais não são predominantemente reguladas pela posição dos indivíduos no mundo da produção, mas organizadas segundo distinções estamentais regradas legalmente 
pelo sistema político. Esta foi uma sociedade de marqueses, viscondes, barões e duques, com privilégios e direitos específicos, e mesmo a base da sociedade não estava imune a diferenciações de cunho estamentais. Manuela Carneiro da Cunha assinala que, nessa configuração, havia três grandes critérios que diferenciavam a gente negra: a cor, a nacionalidade e a condição legal de escravo, liberto ou livre de nascimento. ${ }^{9}$ Assim, os direitos de um africano liberto eram mais limitados do que os de um brasileiro liberto de cor. E "preto" tendia a ser uma classificação utilizada para nominar "escravos" e não pessoas negras livres. Uma organização social que permitia a hierarquização e a divisão da gente negra - uma vez que a despeito da existência de preconceitos de fidalguia e linhagem - a insistência imperial na linha que separava cidadãos e escravos como a divisão fundamental da sociedade permitia a ascensão controlada de pardos e mulatos livres e o surgimento de distinções sociais entre os de baixo.

Quadro 1 - Hierarquias sociais no Brasil no século XIX

\begin{tabular}{|c|c|}
\hline $\begin{array}{c}\text { Homem branco livre, de classe alta } \\
\text { Mulher branca livre, de classe alta }\end{array}$ & linha da classe social \\
\hline $\begin{array}{c}\text { Homem branco livre, de classe média } \\
\text { Mulher branca livre, de classe média }\end{array}$ & linha da cor \\
\hline Homem mulato livre & linha da escravidão \\
Mulher mulata livre & \\
Homem negro liberto & \\
Mulher negra liberta & \\
\hline Homem negro escravo & \\
Mulher negra escrava & \\
\hline
\end{tabular}

Fonte: José Murilo de Carvalho, Pontos e bordados, Belo Horizonte: EDUFMG, 2005, p. 74.

O modelo de estrutura social sugerido por José Murilo Carvalho (Quadro 1) permite visualizar a capacidade da sociedade imperial para multiplicar as hierarquias acima e abaixo da linha da escravidão, assim como enfatizar as limitações do mundo livre no Brasil. O ponto controverso dessa tipologia reside no uso excessivamente abrangente da noção

9 Manuela Carneiro da Cunha, Negros estrangeiros, $2^{\text {a }}$ ed., São Paulo: Companhia das Letras, 2012, p. 38. 
de classe social para designar a concentração de recursos econômicos nessa sociedade. A leitura adequada do quadro implica que o leitor esteja atento ao fato de que a sociedade imperial difere daquelas que os historiadores e sociólogos costumam chamar de "sociedade de classes", referindo-se à emergência das sociedades industriais burguesas europeias. Note-se que os valores e os sentimentos no topo dessa sociedade são os de que aqueles que ocupam as posições mais elevadas constituem uma nobreza de fidalgos, com direitos estatutários dos quais derivam a riqueza e a propriedade - e não o contrário. Outro dado complexo é que a própria linha da escravidão era nativamente designada através da nomenclatura das cores. Conforme argumentou Hebe Mattos, "a noção de 'cor"', herdada do período colonial, não designava, preferencialmente, matizes de pigmentação ou níveis diferentes de mestiçagem, mas buscava definir lugares sociais, nos quais a etnia e a condição estavam indissociavelmente ligadas. ${ }^{10}$

O meu argumento é que a persistência e importância da "cor" como critério de distinção e formação de grupos no pós-abolição deve-se à plasticidade e ambivalência dessa forma de classificação, que incorporou o significado moderno e oitocentista de "raça" sem desclassificar inteiramente os valores do passado. O simbolismo das cores no pós-abolição carrega consigo a tentativa de perpetuação da cultura da escravidão nas relações sociais. Neste sentido, como é possível inferir dos trabalhos pioneiros da escola paulista de sociologia, a imputação "raça" é experienciada pelos libertos e outros negros como uma persistência do passado. ${ }^{11}$ Mas isso é parte da explicação. A intensificação do processo de racialização na conjuntura observada estava relacionada à modernização política da sociedade brasileira, e às reivindicações por liberdade e igualdade, sem referência a origem, nascimento e cor.

10 Hebe Mattos, Das cores do silêncio: os significados da liberdade do sudeste escravista (Brasil, século XIX), Campinas: Ed. Unicamp, 2013, p. 106.

11 Fernando Henrique Cardoso, Capitalismo e escravidão: o negro na sociedade escravocrata do Rio Grande do Sul, Rio de Janeiro: Paz e Terra, 1997; Octávio Ianni, As metamorfoses do escravo, São Paulo: Hucitec, 1988; Florestan Fernandes, A integração do negro na sociedade de classes, São Paulo: Globo, 2008. 


\section{A crise do escravismo no Maranhão}

Como essa realidade se configurou na sociedade maranhense? É o problema ao qual me dedico nas próximas seções. Destacarei aqui a crise do escravismo no Maranhão com relação a três fatores que deram uma feição particular ao processo de racialização da região estudada: a importância demográfica da gente livre de cor; as dificuldades de controlar o território numa região de fronteira e a posição periférica da administração local e de suas demandas no âmbito do Estado nacional.

O atual estado do Maranhão possui uma história bastante singular no quadro das regiões que formaram o Império brasileiro, posto que integrou, junto ao Pará e ao Amazonas, o chamado estado do Maranhão e Grão-Pará, um domínio colonial português separado do antigo estado do Brasil. Toda essa porção setentrional, à exceção da Bahia, de Pernambuco e do Rio de Janeiro, foi integrada ao tráfico massivo de escravos apenas na segunda metade do século XVIII, como fruto da política de proteção de fronteiras, povoamento, dinamização econômica e integração regional da colônia sul-americana, instituída pelo Marquês de Pombal. Pode-se dizer que o boom do escravismo maranhense, centrado na exportação do algodão, integra o fenômeno que Dale Tomich chamou de "segunda escravidão", para caracterizar o surgimento de plantações escravistas conectadas à Revolução Industrial - no caso, à indústria têxtil inglesa. ${ }^{12}$ No ano de 1815, o Maranhão tornou-se capitania brasileira que, proporcionalmente, continha a maior população de pessoas escravizadas em todo o Império brasileiro ( 78 mil pessoas, cerca de $55 \%$ da população). ${ }^{13}$ A pecuária, mais ao sul da capitania, e a produção de arroz, farinha e, em menor escala, açúcar, também compunham importantes setores dessa economia de exportação.

Entretanto, múltiplos fatores ameaçaram a centralidade do latifúndio como sistema de eito na economia maranhense, assim como os estilos de vida senhoriais e aristocráticos sustentados pela escravidão, a saber: a queda progressiva dos preços do algodão no mercado inter-

12 Cf. Dale Tomich, Pelo prisma da escravidão, São Paulo: Edusp, 2011.

13 Regina Hela Faria, Mundos do trabalho no Maranhão oitocentista: os descaminhos da liberdade, São Luís: EDUFMA, 2012, pp. 63-64. 
nacional, a partir da década de 1820; a concorrência com o algodão dos Estados Unidos; o pouco avanço tecnológico das plantações; a eclosão da Balaiada (1838-1841); o encarecimento do preço de africanos, frente às pressões abolicionistas inglesas e sua interrupção formal em 1850; e o crescimento de setores econômicos desvinculados da exportação de base escravista, voltados à produção para subsistência e a um incipiente mercado interno. A abolição definitiva seria o ponto culminante desse lento processo de declínio.

Em contraste gritante com o Sudeste e o Sul do Brasil, o que caracteriza o pós-abolição maranhense não é a metamorfose do senhor de escravos no grande latifundiário que submete homens livres e libertos, dependentes da grande lavoura, mas sim a expansão da pequena produção camponesa de moradores e foreiros, das terras de preto e de outras formas de uso comum dos recursos; da produção para subsistência; e da manutenção da força do capital comercial-usurário no controle da rede de intermediações comerciais, sustentadas pela proteção da oligarquia política. ${ }^{14}$

É interessante comparar o caso maranhense com as outras grandes províncias escravistas do norte agrário, como a Bahia e Pernambuco. A região do chamado Recôncavo baiano, sobretudo as grandes lavouras de Maragogipe e São Francisco do Conde - além de áreas do extremo sul daquela província, como Caravelas e Vila Viçosa -, notabilizaram-se pela enorme quantidade de pessoas escravizadas até a assinatura da Lei Áurea, a despeito da crise econômica que atingiu a produção açucareira. Conforme sugere B. J. Barickman, isto se deveu à alta oferta de africanos escravizados que caracterizou a região desde os tempos coloniais, tendo sobrevivido clandestinamente à proibição do tráfico negreiro, em 1850. Por outro lado, os senhores de engenho da região puderam enfrentar a crise econômica, diversificando a produção com investimentos no plantio de café e na indústria do fumo. O alto número de escravos também se deve à escassez de mão de obra livre, visto que esta população encontrava na agricultura de subsistência, bem como na produção de farinha para mercados locais, alternativas mais atrativas do que o trabalho na grande

14 Conforme sintetizou Flávio Reis, Grupos politicos e estrutura oligárquica no Maranhão, São Luís: Edição do Autor, 2013, p. 38. 
lavoura, preferindo migrar para a zona de expansão do cacau, ao sul da província, ou mesmo para a capital, Salvador. Esses foram alguns dos motivos que fizeram do dia 13 de maio uma data de ruptura dos padrões estabelecidos nas relações de trabalho no Recôncavo. ${ }^{15}$

No Maranhão, a crise econômica do sistema agroexportador, capitaneado pela produção do algodão, tornou-se incontornável na década de 1850, quando o tráfico atlântico de africanos se tornou ilegal. Aliás, desde a primeira metade do século XIX, as rotas equatorianas dos tumbeiros com destino ao Maranhão sofreram com a intensa fiscalização inglesa. ${ }^{16}$ Outro dado importante nessa comparação é que, no Maranhão, a população livre de negros, pardos e caboclos começou a suplantar o trabalhador escravizado na própria lavoura escravista. Se no ano de 1821, dos 106.228 trabalhadores do campo maranhense, 69.534 eram escravos - aproximadamente, $77 \%$ do total -, a situação praticamente se inverte no recenseamento imperial de 1872. Dos 106.899 trabalhadores contabilizados no início da década de 1870, existiam 19.960 cativos, representando apenas $22 \%$ desse grupo. ${ }^{17}$

Paradoxalmente, o dado que em 1872 caracteriza o Maranhão no conjunto das províncias brasileiras é a combinação entre a importância demográfica da população livre e a manutenção da relevância da escravidão. De acordo com os Gráficos 1 e 2, a província possuía uma população de tamanho médio para os padrões brasileiros e, em termos proporcionais, concentrava a terceira maior população cativa do país, aproximando-se assim daquelas províncias que importavam escravos do norte agrário para a rentável lavoura cafeeira, como São Paulo e Rio de Janeiro.

15 Cf. B. J. Barickman, "Até à véspera: o trabalho escravo e a produção de açúcar nos engenhos do recôncavo baiano (1850-1881)", Afro-Ásia, n. 21-22 (1998-1999), pp. 177-238; e Iacy Maia Mata. "Libertos de treze de maio e ex-senhores na Bahia: conflitos no pós-abolição", Afro-Ásia, n. 35 (2007), pp. 163-198.

16 Walter Hawthorne, From Africa to Brazil: Culture, Identity, and Atlantic Slave Trade, 16001830, Nova York: Cambridge University Press, 2010, pp. 118-119.

17 Regina Helena Faria, "Demografia, escravidão africana e agroexportação no Maranhão oitocentista", Ciências Humanas em Revista, n. 2 (2004), p. 92. 


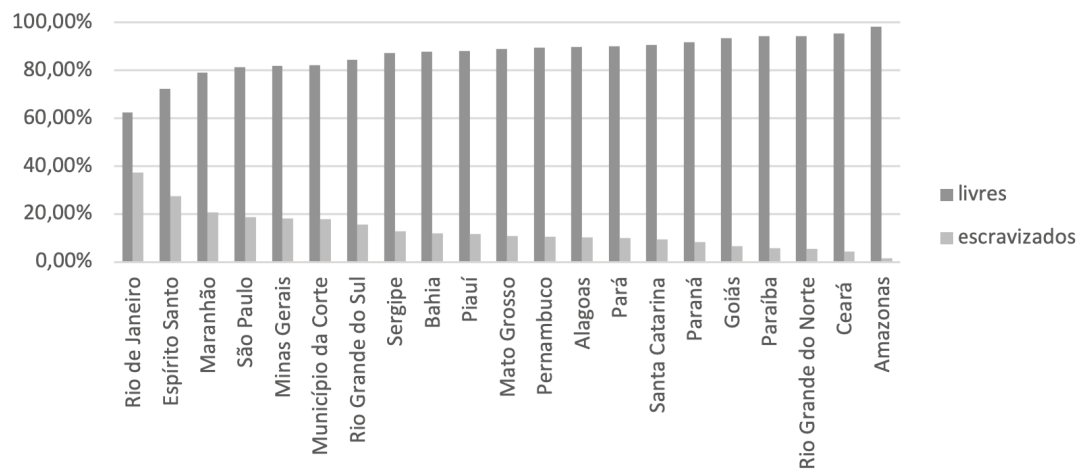

Fonte: Recenseamento Geral do império do Brasil de 1872. DIRETORIA GERAL de Estatística, Recenseamento Geral do Império de 1872. Rio de Janeiro, Typ. Leuzinger/Tip. Commercial, 1876, 12 volumes.

Gráfico 2 - População brasileira por província (1872)

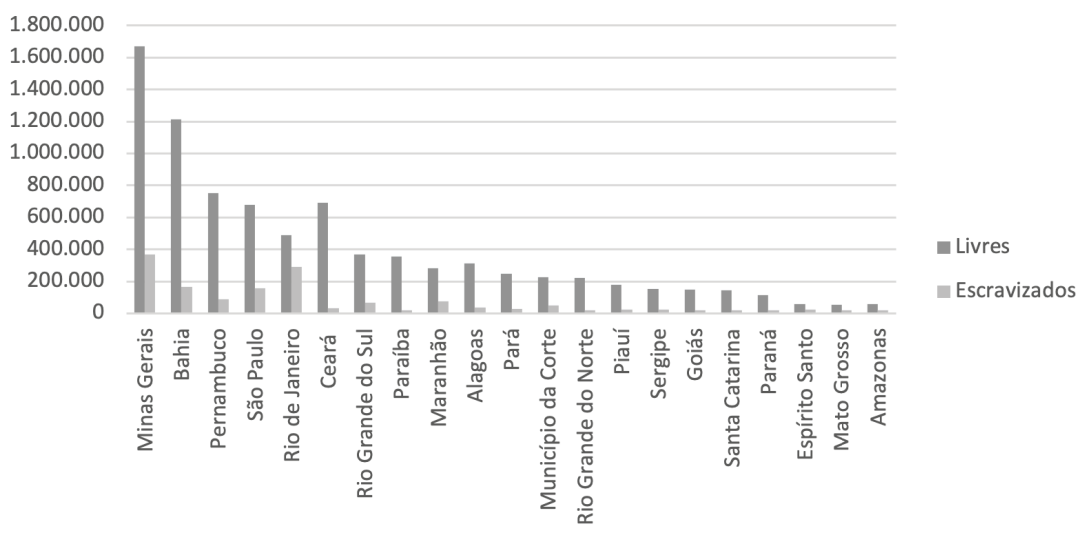

Fonte: Recenseamento Geral do Império do Brasil de 1872. DIRETORIA GERAL de Estatística, Recenseamento Geral do Império de 1872. Rio de Janeiro, Typ. Leuzinger/Tip. Commercial, 1876, 12 volumes.

Esses dados apontam para a combinação explosiva entre a relevância da escravidão - sobretudo nas áreas urbanas, como São Luís, Codó, Alcântara e Caxias, onde prevaleceria uma etiqueta estamental nas relações de trabalho - e a presença de uma população livre, majoritariamente negra e mestiça, ciosa dos seus precários direitos. Já antes da abolição, tornava-se patente o conflito em torno da coerção, do disciplinamento 
e da manutenção do domínio sobre a mão de obra, assim como a resistência daqueles que almejavam emancipar-se da plantação escravista e dos sistemas análogos de sujeição. Como veremos na próxima seção, os usos sociais de códigos escravistas de distinção entre grupos, simbolizado através da nomenclatura das cores, para subjugar uma gente majoritariamente livre impulsionou a configuração do racismo moderno na sociedade maranhense.

Por ora, vale a pena destacar que, em termos de importância da população livre na grande lavoura, o caso maranhense é mais parecido com Pernambuco. Mas, à diferença dos maranhenses, a aristocracia senhorial pernambucana conseguiu lidar com o crescimento dos trabalhadores livres na plantação escravista de maneira gradual e controlada, contando com o monopólio das terras férteis da província, a modernização dos engenhos e a transferência dos custos da produção para a mão de obra livre dependente da grande lavoura. As oportunidades de vida para a população livre fora do latifúndio eram limitadas pelas dificuldades da região do semiárido e pelas fortes estiagens. ${ }^{18}$ No Maranhão, a lavoura escravista foi marcada pela ausência de investimentos na modernização da produção - o que impediu a redução de custos - e pela ausência do controle senhorial sobre as abundantes terras férteis e devolutas. ${ }^{19}$ Tal problema tornou a libertação dos cativos um processo moroso, mas não exatamente "controlado" pelos senhores maranhenses.

Os problemas da elite política e dos proprietários de terra com relação à administração e ao controle do território é uma evidência desse fato. Um dos aspectos que caracterizam a paisagem do Maranhão durante o século XIX é a abundância de quilombos. Trata-se de uma sociedade de escravos fugidos em quilombos que também abrigavam desertores e outros homens livres pobres, desejosos de escapar da dependência social e econômica das grandes plantações escravistas. De acordo com Assunção, "pode-se afirmar que no Maranhão existiram poucas fazendas escravistas sem quilombos ao seu redor”, pois, ao contrário do nordeste

18 Peter Eisenberg, Modernização sem mudança: a indústria açucareira em Pernambuco 18401890, São Paulo: Paz e Terra, 1977 pp. 201-202.

19 Francisco de Assis Leal Mesquita, Vida e morte da economia algodoeira do Maranhão: uma análise das relações de produção na cultura do algodão (1850-1890), São Luís: EDUFMA, 1987, pp. 115-118. 
açucareiro, a geografia maranhense era marcada por extensas matas, com muitos rios e riachos que dificultaram a interiorização da lavoura escravista e escaparam do controle militar por parte do governo. A geografia, em suma, favoreceu a criação de enclaves nos rincões das florestas mais próximas à cabeceira dos rios. ${ }^{20}$

A abundância de quilombos e de outras formas de uso comum da terra no Maranhão, como as chamadas terras de santo, terra de preto e terra de índio, estão ligadas historicamente à crise econômica das plantações escravistas de algodão e açúcar da região. Cientistas sociais documentaram, mais recentemente, a existência no estado de diversas comunidades negras rurais que se originaram da ocupação de terras abandonadas por proprietários falidos ou sem condições de realizar investimentos, ou ainda por meio de doações de seus antigos senhores. ${ }^{21}$ As chamadas terras de preto constituem um dos fenômenos mais complexos da derrocada do mundo escravista brasileiro e explicitam o surgimento de um campesinato livre, expressivamente negro e mestiço, antes da abolição. Há casos muito antigos, como a comunidade negra de Bom Sucesso, existente no município de Mata Roma, no Maranhão oriental. Segundo a memória oral, Bom Sucesso data ainda da primeira metade

20 Mathias Assunção, "Quilombos Maranhenses", in João José Reis e Flavio dos Santos Gomes (orgs.), Liberdade por um fio: história dos quilombos no Brasil (São Paulo: Companhia das Letras, 1996), p. 436. Flavio Gomes chamou a atenção para importância dos quilombos localizados próximos às margens do Rio Turiaçu, os quais permaneceram ali até o pós-abolição, apesar das sucessivas ondas de repressão que enfrentaram no século XIX. Segundo o historiador, a dificuldade de desfazer por completo essas comunidades é que não bastava ocupar essas áreas na floresta, sendo necessário integrá-las ao poder do Estado e às redes mercantis vinculadas à plantação escravista. Os relatos das expedições militares contra esses mocambos descrevem a existência de uma "economia quilombola" especializada na venda de gêneros alimentares para as vilas mais próximas, contando com engenhos de moer cana, roças de subsistência e com o garimpo do ouro para troca e comercialização na fronteira com o Pará. Um estilo de vida muito atraente para a parcela do campesinato negro que desejava se livrar do latifúndio, antes e depois da abolição de 13 de maio. A esse respeito, cf. Flávio dos Santos Gomes, "Roceiros, mocambeiros e as fronteiras da emancipação no Maranhão", in Flávio dos Santos Gomes e Olívia Maria Gomes (orgs.), Quase-cidadão: histórias e antropologias do pós-emancipação no Brasil, (Rio de Janeiro: Ed. FGV, 2007), pp. 147-169.

21 Alfredo Wagner B. Almeida, Terra de quilombo, terras indígenas, "babaçuais livres", "castanhais do povo", faxinais e fundos de pasto: terras tradicionalmente ocupadas, Manaus: PGS-UFAM, 2008, pp. 144-145. 
do século XIX, originária de terras doadas a trabalhadores escravizados pelo brigadeiro Anacleto Henriques Franco. ${ }^{22}$

Pesquisas antropológicas fizeram descobertas relevantes quanto às concepções de liberdade que orientaram a formação desse campesinato negro. Na comunidade de Bom Jesus dos Pretos, onde as terras foram adquiridas na conjuntura da abolição, o antropólogo Luiz Eduardo Soares observou que, no mito de origem do grupo e na memória coletiva, o ato de supressão da escravatura, atribuído à princesa Isabel, é interdependente com doação das terras pelo antigo senhor. Para os pretos de Bom Jesus, "a liberdade não existe, realmente, sem o acesso franqueado à terra, sem o controle sobre o meio de produção essencial e a moradia independente, em território próprio ou livre, equivalente à autonomia da vida doméstica e familiar." ${ }^{23} \mathrm{O}$ amálgama entre a conquista formal da liberdade, no 13 de maio, e os direitos sobre a terra contrapõe-se à ideia e à memória do cativeiro. ${ }^{24}$

Diante do crescimento no número de homens livres, de cor - foreiros e moradores - a principal alternativa política sugerida aos senho-

22 Benedito Souza Filho, Bom Sucesso: terra de preto, terra de santo, terra comum. São Luís: EDUFMA, 2008, p. 135.

23 Luiz Eduardo Soares, Campesinato: ideologia e política. Rio de Janeiro: Zahar, 1981, p. 39.

24 Alfredo Wagner de Almeida destacou a importância da categoria "tempo livre" na representação do pós-abolição entre os moradores das terras de preto, na cidade de Alcântara, importante centro do escravismo maranhense: a desintegração progressiva da autoridade dos senhores de escravos e de seus prepostos corresponde à emergência de uma representação do trabalho desvinculada de qualquer forma de subordinação pelos membros das famílias de ex-escravos. Sua liberdade repousa em controlar, de maneiras diversas, o acesso aos meios de produção, os seus meios de trabalho e o tempo equilibrado entre o trabalho para si e as formas de entretenimento. Sobre a comunidade negra de Bom Sucesso, afirma o antropólogo Benedito Souza Filho: "O que nos leva a pensar a relação entre identidade e território é justamente o fato de que não conseguem separar a caracterização social - descendentes - do direito às terras doadas pelos seus ancestrais. Apesar de existirem diferentes povoados, esse conjunto é pensado como constituindo uma única unidade territorial, referida, entre outros elementos, a laços de consanguinidade, associados às categorias preto e descendente. [...] Os contextos em que essa referência aparecia estavam sempre ligados à passagem de escravos a herdeiros". Cf. Alfredo Wagner B. Almeida, Ideologia da decadência, Manaus: Casa 8/ Fundação Universidade do Amazonas, 2008, p. 121. Conforme Luiz Eduardo Soares, a relação entre herança, terra, liberdade e identidade étnica também é relevante no caso de Bom Jesus dos Pretos: "A noção de 'herança' congrega os traços pertinentes do parentesco, da etnia e da história: todo herdeiro das terras do Bom Jesus é negro e todo negro de Bom Jesus é herdeiro, porque todo negro [...] é descendente de escravos e as terras foram doadas aos escravos 'pra criar filhos e netos'. A herança associa identidade étnica e genealógica à posse coletiva das terras, designada como 'direito' fundamental, pressuposto da liberdade.” Cf. Soares, Campesinato, p. 41. 
res era investir na imigração estrangeira, preferencialmente na europeia, conforme insistiam os políticos e fazendeiros de São Paulo, Rio de Janeiro, Paraná e Rio Grande do Sul. Mas, no início dos anos 1870, a história da imigração estrangeira no Maranhão já colecionava fracassos. Essa questão fora levada a sério na administração de Eduardo Olímpio Machado que, na década de 1850, instalara sete colônias na província, totalizando 887 imigrantes estrangeiros (707 portugueses, 140 açorianos e 40 chineses). Nenhuma delas perdurou até a década seguinte. ${ }^{25}$ Ainda assim, em 26 de julho de 1867, foi criada a Comissão Auxiliadora da Imigração e Colonização, cujos projetos não saíram do papel. Em flagrante contraste com as províncias do Sul do país nas últimas décadas do cativeiro, a imigração estrangeira estava desacreditada como solução econômica para a crise da lavoura escravista, na província do Maranhão.

Em 25 de julho de 1877, o deputado do Partido Conservador maranhense Augusto Olímpio Gomes de Castro afirmava, na Assembleia Geral no Rio de Janeiro, que se era "com a colonização estrangeira que pretende o governo amparar a lavoura do norte, como filho daquelas regiões, e nesta casa o mais obscuro dos seus representantes (muitos não apoiados), agradeço-lhe o benefício, pois não a encontrará morta, mas enterrada." ${ }^{26}$ Para o político - um descendente de famílias escravistas e aristocráticas de Alcântara que se tornaria o futuro chefe da agremiação conservadora em seu estado no pós-abolição - não havia um problema de falta de braços no Maranhão, mas no modo de vida das "classes inferiores", no sistema de transportes e na descapitalização do latifúndio.

As condições especiais do país facilitam e protegem a inação e ociosidade das classes inferiores. A produção atual é o resultado do trabalho escravo; talvez não atinja a um terço da população livre que se entrega seriamente ao trabalho (apoiados).

A facilidade da subsistência por um lado, o atraso em que se acham as classes inferiores de outro, explicam e mantém essa situação deplorável. Digo-o, cheio de dor, as últimas camadas do nosso povo não têm bem distintas as noções da propriedade e da família.

26 Diário do Maranhão, São Luís, 25 jul. 1877, p. 1. 
Devora-as a lepra do concubinato, não têm outras necessidades que não sejam as naturais, e essas mesmas muito facilitadas pela ação do clima e fertilidade do solo.

É por isso que entendo que nunca serão demais os esforços empregados na instrução do povo, instrução literária e religiosa, que lhe dê exatas noções de propriedade e da família, que lhe faça sentir que o homem não trabalha somente para matar a fome, como os outros animais, mas para elevar o seu nível moral, para os filhos que procriou e deve educar para a pátria que dele levantar a maior grandeza e esplendor.

As necessidades que apoquentam e trazem os lavradores em contínuo sobressalto são, no meu humilde conceito, a falta de capitais e de meios de transportes (muitos apoiados). ${ }^{27}$

A citação é relevante porque destaca a posição periférica das elites políticas maranhenses e suas demandas frente ao Estado nacional. Conforme Evaldo Cabral de Mello, esse tipo de situação marcou toda a elite política nordestina nas últimas décadas do Império brasileiro. ${ }^{28}$ Do ponto de vista de Gomes de Castro, os impasses ao desenvolvimento do Maranhão seriam decorrentes da desatenção do governo central quanto à descapitalização da lavoura, somada à ausência de uma política de transportes voltada a viabilizar as trocas comerciais entre o interior de onde saía a maior parte da produção - e a capital da Província - que monopolizava o setor comercial. Fica patente a consciência senhorial de que, sem a participação do Estado imperial, não haveria como subjugar a população livre. Tal discurso possuía um foro ampliado no norte agrário. No Congresso Agrícola do Recife (1878), por exemplo, a sensação de desprestígio político frente à zona cafeeira das províncias do sul do Império e a busca de alternativas para manter o trabalhador livre nacional atrelado ao latifúndio ocuparam as preocupações dos presentes. ${ }^{29}$ No Maranhão, esse discurso ganhava uma força ideológica particular, à

27 Diário do Maranhão, São Luís, 25 jul. 1877, p. 1.

28 Evaldo Cabral de Mello, O norte agrário e o império (1871-1889), Rio de Janeiro: Topbooks, $2^{a}$ ed., 1999, p. 17.

29 Cf. Peter L. Eisenberg, Homens esquecidos: escravos e trabalhadores livres no Brasil: séc. XVIII e XIX, Campinas: Ed. Unicamp, 1989. 
medida que a desagregação das grandes plantações em pequenos roçados, cultivados por homens e mulheres livres, se tornava mais visível.

Nessa perspectiva periférica em relação ao Estado nacional, os desafios da elite política e senhorial maranhense eram sentidos e explicados como fruto do "atraso" cultural das "classes inferiores". Se lidas nessa chave, as dificuldades econômicas para sustentar a plantação escravista; as possibilidades de ocupação de terras devolutas e férteis por quilombolas, caboclos, desertores, e indígenas; e os parcos direitos da população livre foram apontados como razões substantivas para a chamada "decadência" do Maranhão. ${ }^{30}$ Essa formulação, tão bem traduzida no pensamento escravista de Gomes de Castro, revela os conteúdos ideológicos que moldaram a noção de "povo", que integrará o vocabulário da oligarquia política regional durante a Primeira República (1889-1930). Nesse contexto, o termo se refere a uma população considerada aquém do marco civilizatório europeu, sem qualquer noção de família, propriedade, entregue às necessidades mais animais da vida biológica do corpo e moralmente reduzida ao estado de natureza, enfim, um povo cada vez mais imaginado como "mestiço" e "negro."

\section{Os "preconceitos de raças" e a abolição}

A construção desse tipo de imaginário racial, constitutivo da sociedade brasileira de fins do século XIX, vincula-se, nesse caso, às condições sociais da província - dificuldades para controlar grandes populações numa região de fronteira, a relevância demográfica da população de cor livre e a posição periférica das elites locais e regionais - e às experiências negras de emancipação que marcaram o fim da escravidão naquela porção do norte agrário. Observadores sociais da realidade maranhense, como Dunshee de Abranches e Aluísio Azevedo, notaram que o crescimento do movimento abolicionista no país, a paulatina libertação dos cativos e a intensificação do sentimento de decadência em meio à aristocracia senhorial do Maranhão implicaram no aumento da valorização simbólica da cor como critério de distinção social. 
Casar com um bode (era a expressão chula com que se estigmatizavam os mulatos) ou com um pardo, nome mais polido com que estes eram também designados, constituía uma desonra irreparável e perpétua. A geração ficava para sempre tisnada. Nas polêmicas jornalísticas eram fatais as alusões aos que não provinham de raça pura ou eram injustamente inquinados de haver berrado do ventre materno. [...] O catedrático de geografia do Liceu, o popularíssimo Dr. Tibério, por sua cor morena carregada, era alvo de alusões ferinas de alunos irreverentes. Certo dia, no quadro negro da sua aula, escreveram em fortes caracteres: "Tibério é bode." O velho professor entrou na sala: mirou com o seu lendário lorgnon o dístico desrespeitoso; e sem se irritar, pegou no giz e respondeu abaixo: "Companheiro de vocês." Em seguida, do alto de sua cátedra, começou a recitar versos de famosa sátira - A Bodarrada, comentando-os com alusões ferinas a pais e parentes dos discípulos, que desconfiara serem os autores da frase agressiva. Houve sérios protestos das famílias que se julgaram ofendidas. ${ }^{31}$

É muito simbólico que o professor de geografia tivesse evocado um poema do abolicionista negro Luiz Gama (1830-1882) para se defender do preconceito de cor. A imagem é sugestiva, quanto às conexões entre a luta pela ampliação da cidadania e a reelaboração de novas hierarquias sociais através das antigas classificações de cor. No romance $O$ mulato (1881), o escritor Aluísio Azevedo (1857-1913) problematiza a relação entre a ideia de que o fim da escravidão propulsionaria uma modernização social. Pode-se dizer que o enorme sucesso desse livro - que inaugura o naturalismo brasileiro - deve-se ao fato de ter sido transformado numa espécie de libelo intelectual a respeito da questão da cor, contribuindo para pautá-la como um problema relevante do ponto de vista nacional. Numa das cenas de maior impacto do romance, quando o rico e erudito Raimundo descobre que sua cor é a razão pela qual lhe é negado o casamento com sua amada, o narrador descreve algo que poderia ser visto como um novo processo de subjetivação racial:

Não the dou minha filha, porque o senhor é mulato!... Si me dissesse - é porque é pobre! Que diabo - eu trabalharia! Si me

31 Dunshee de Abranches, O cativeiro, São Luís: Alumar e AML, 1992, p. 34. 
dissesse - é porque não tem uma posição social, juro-te que a conquistaria, fosse como fosse! - É porque é um infame! Um ladrão! Um miserável! - eu me comprometeria a apresentar o melhor modelo dos homens de bem! Mas um mulato!... E como hei de transformar todo meu sangue - gota por gota? ${ }^{32}$

Destaco na citação a questão de fundo abordada no romance, qual seja, a importância da categorização racial. A agonia da personagem é atravessada pelo sentido mais profundo e essencialista que as classificações de cor foram adquirindo, conforme avançava o processo de emancipação no país. O uso de tais categorias vinha de longa data, mas elas passavam então a se referir a uma natureza constitutiva do sujeito, impossível de ser perdida ou conquistada na luta social, visível na pele e no comportamento dos indivíduos. Nesse sentido, Aluísio Azevedo captura, na ficção, o novo significado racial do uso nativo das cores.

Na década de 1880, constatava-se, nas principais faculdades do Império brasileiro, a hegemonia intelectual de teorias científicas que apostavam no determinismo racial e climático para explicar o estágio das sociedades na evolução humana. ${ }^{33}$ Essa ideologia também impregnou os bacharéis e médicos maranhenses, formados pelas faculdades de Direito do Recife e de São Paulo e pelas faculdades de Medicina do Rio de Janeiro e da Bahia. Aliás, o mais famoso representante do chamado racismo científico no Brasil é o médico maranhense Raimundo Nina Rodrigues (1862-1906), em especial por sua obra As raças humanas e a responsabilidade penal no Brasil (1894), na qual defende que mestiços e negros deveriam ser julgados por um código criminal especial dada a sua inclinação biológica ao crime. ${ }^{34}$

Mas ele não foi o único. Também é revelador o estudo de doutorado Do parto e suas consequências na espécie negra (1887), de autoria do doutor Justo Jansen Ferreira (1864-1930), oriundo de abastada família

32 Aluísio Azevedo, O mulato, São Luís: Typ. do Paiz, 1881, p. 395.

33 Cf. Lilia Moritz Schwarcz, O espetáculo das raças: cientistas, instituições e questão racial no Brasil (1870-1930). São Paulo: Ed. Companhia das Letras, 1993; Thomas Skidmore, Preto no branco: raça e nacionalidade no pensamento brasileiro. São Paulo: Paz e Terra, 1976.

34 Cf. Mariza Corrêa, As ilusões da liberdade: a escola de Nina Rodrigues e a antropologia no Brasil. Bragança Paulista: Edusf, 1998. 
da cidade de Caxias. O uso do termo "espécie" no título da tese indica o quão longe foi a ideia de que negros e brancos não compartilhavam da mesma humanidade. O médico maranhense, apoiado em bibliografia considerada científica, afirma que os negros são menos sensíveis à dor física, fator que seria tão mais intenso quanto menor a inteligência da pessoa. ${ }^{35}$ As explicações disponíveis para o fenômeno consideravam que "os negros expõem desde a sua infância a sua pele aos raios ardentes do sol, adquirindo o tegumento externo uma densidade considerável, a qual explica a obtusão à sensibilidade tátil."36 Também havia especulações quanto à disposição anatômica diferenciada, na raça negra, das "terminações periféricas dos nervos" que, "sendo o meio pelo qual se comunicam as impressões externas ao cérebro, explica a pequena ou a menor percepção e portanto - o desenvolvimento intelectual do negro inferior ao das outras raças." ${ }^{37}$ Assim, velhos preconceitos sociais e culturais ganharam o prestígio da autoridade científica, conformando um novo fundamento à desigualdade social.

Um dos ramos mais populares da nova ciência das raças foi a antropologia criminal e, em particular, a frenologia, dedicada à investigação do cérebro humano. Neste sentido, a análise das motivações criminosas deveria incorporar o princípio científico de que "o homem deve ser estudado nos próprios elementos indissolúveis que o compõem com todas as suas qualidades físicas e psíquicas, como agente e agido no ambiente que o circunda e que é o meio em que se pode conceber vivo."38 Tal concepção pretendia fazer letra morta do princípio de livre arbítrio, ao considerar que a ação humana, sobretudo a de pessoas consideradas

35 A esta inferência teórica, o autor soma uma observação empírica: "Nos partos que observamos com relação à matéria notamos que a maior parte das vezes logo que o trabalho de parto se declarava, as mulheres tornavam-se mais concentradas, menos expansivas e com certa calma esperavam a terminação. No corrente ano deu-se o seguinte fato aliás muito interessante com uma negra que ocupava o leito n. 15 da Maternidade da Faculdade de Medicina. Esta mulher, sem que fenômeno algum doloroso lhe indicasse a aproximação do parto, foi acometida de uma sensação de peso no baixo ventre; buscando satisfazer a necessidade natural, foi surpreendida pelo nascimento de seu filho, sem que tivesse tempo de voltar ao seu leito!.", Justo Jansen Ferreira, Do parto e suas consequências na espécie negra, Rio de Janeiro: Typ. Laemmert \& C., 1887, pp. 35-36.

36 Ferreira, Do parto e suas consequências, p. 35.

37 Ferreira, Do parto e suas consequências, p. 35.

38 A Pacotilha, 18 mar. 1888, p. 2. 
anormais, não é determinada pela subjetividade, mas pela conexão entre a biologia dos corpos, o ambiente e fatores psíquicos. Assim, "na antropologia criminal [...] a parte anatômica é só o fundo do quadro, um apêndice da psicologia criminal que, entretanto, tem necessidade de uma base anatômica, sob pena de vê-la esvoaçar nas nuvens e desaparecer."39

A importância crescente das teorias raciais, o avultado número de homens de cor livres e o mencionado sentimento de decadência da aristocracia senhorial maranhense configuraram um espaço social em que a antiga nomenclatura das cores, antes utilizada para distinguir senhores e escravos, foi mobilizada para hierarquizar negros e brancos. A aparição dessas categorias como "novos" grupos sociais resultava de uma reconfiguração da sociedade imperial, em meio ao processo de emancipação.

A revalorização simbólica das categorias de cor, cujo emprego começa a se distinguir sutilmente do seu corrente uso no marco escravista de classificação social, já era visível nos anúncios de trabalho presentes em jornais de grande circulação na cidade de São Luís, no primeiro semestre de 1888 - precisamente, nos cinco meses que antecederam a assinatura da Lei Áurea. Esses classificados continham um campo de ambivalência, suscitada pelos sentidos não unívocos de categorias como "negrinha" e "moleque" que se voltavam à caracterização de tipos sociais. As designações compunham o repertório de cores e nomes utilizados para classificar crianças, adolescentes e jovens sob o cativeiro. Isto é perceptível, por exemplo, no anúncio da fuga de um "moleque", pois ali a menção à cor preta aparece como forma de substancializar a posição social dessa pessoa enquanto escrava (Figura 9). Mas a esse respeito, é preciso notar que, nas últimas décadas da escravidão, o campo semântico das palavras "moleque" e "negrinha" foi paulatinamente ampliado, a fim de tornar mais evidente que eles se referiam também a serviçais livres, recrutados para os trabalhos manuais costumeiramente designados aos escravos (Figuras 1, 2 e 4). À medida que as cores ficaram subsumidas em outras categorias classificatórias, a utilização da cor, no contexto da derrocada do escravismo, alargou os limites da subjugação de grupos, ao naturalizar ainda mais as diferenças sociais e culturais. 


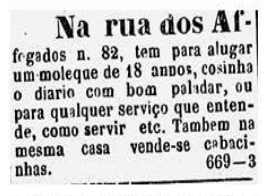

A Pacotilha, 11 de Fevereiro de 1888 p. 1 FIG 1.

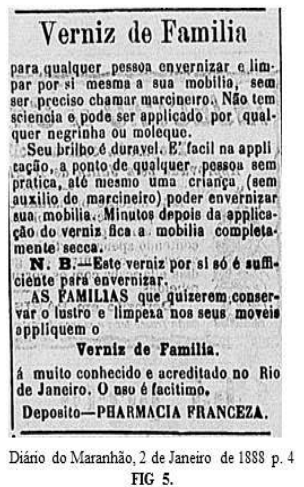

Augada.

A ruo dos Afrugados, casa n. 17, tem uras preta co: inbeira para
alugar se. $648-3$ A Pacotilha, 11 de Fevereiro de 1888 p. 1 FIG 8.

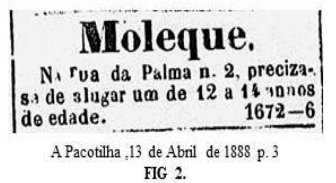

\section{Na quinta das Sr. ${ }^{\text {a }}$ Frias a rua do Apleum ou nesta typo-
graphia precisa-se alugar um moleque graphia precisa-se
ou uma negrinha \\ A Pacotilha, 3 de Janeiro de 1888 p. 3} FIG 4.

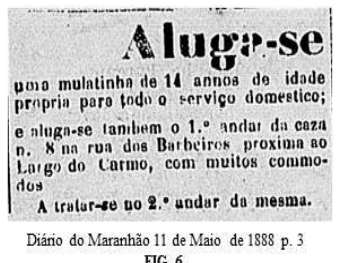
FIG 6.

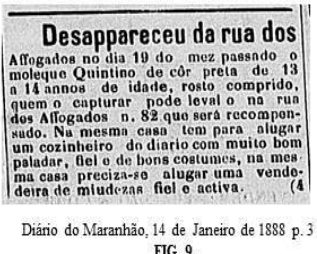

\section{Criada.}

Tem uma livre, na Trindade, casi n. 22, que deseja slugsr se, para serviço interno cue case de familia; sabe gommar, preparar vestidos da moda $e$ todo 0 arr? $0 j n$ censarnente a u na cass. $1674-3$

A Pacotilha, 13 de Abril de 1888 p. 3 FIG 3.

\section{Negrinha}

Na primeirn casa de azulejo, no principio clu rua dos Remedios á mão direita de quem vas para o largo, precisa se alugar uma negrinha de 10 para 12 annos qut scja morigerads e tenha bons costumes. Pagr-ee bem agr'rdando

O Paiz 21 de Janeiro de 1888 p. 3 FIG 7.

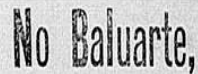

ualet $1.98 \%$, precisa-se al nzar uma negrinlis out.um moleque de 10 a 12 annos, mais ou menos, yue le. aha bons costumes-para sarvico lomesticu.

O Paiz, 30 de Abril de 1888 p. 3 FIG 10.

Isto também se faz perceber quando os anúncios combinam menções à cor junto às qualidades desejáveis aos serviçais, como o fato de serem "fiéis", "morigerados" e de "bons costumes" (Figuras 7, 9 e 10). Os anúncios de trabalho são fontes interessantes, pois, diferentemente dos artigos de jornais, dos escritos memorialísticos e dos romances, eles mostram a construção cultural de tipos sociais, como "moleques", "negrinhas", "criadas", "alugadas" etc. A presença dessas descrições permite inferir como o mundo do trabalho clivou o espaço da cidadania pela via da cultura, por meio de um alargamento dos sentidos dos códigos e critérios de distinção existentes, na tentativa de atualizar a tutela senhorial. A questão se amplia quando se tem em mente que, no fim do século XIX, mesmo abolicionistas convictos desconfiavam da "personalidade 
do escravo", que entendiam como sendo refratária à "personalidade moral do cidadão", assumindo que os escravos não saberiam fazer bom uso da liberdade. Não sem razão, o debate sobre as formas de recrutamento de trabalhadores negros no pós-abolição acentua a importância de uma dimensão ética, disciplinar e civilizatória do trabalho, como via de integração dos libertos aos valores europeus. ${ }^{40}$

O conjunto desses anúncios fornece pistas sobre a ressignificação racial das categorias de cor e outras classificações como "criadas" e "moleques". Um anúncio como o "Verniz de Família" (Figura 5) expõe o caráter completamente naturalizado da relação entre cor e subalternização social, por meio da frase: "não tem sciencia e pode ser aplicado por qualquer negrinha ou moleque." Digno de nota é o anúncio "Criada" (Figura 3), em que o estatuto social da pessoa - "livre" - reforça o campo imaginário da cor e seu suposto perfil cultural: "tem uma livre, na Trindade, casa n. 22, que deseja alugar-se.” A menção à liberdade da trabalhadora seria desnecessária, caso o anúncio falasse da contratação de uma criada branca. Em outros casos, a menção explícita da cor pretende objetivar o "tipo social" a ser recrutado, bem como os modelos de relações de trabalho consolidados, como no caso da "mulatinha de 14 anos", anunciada dois dias antes da abolição, e da "preta cozinheira", que se alugava em fevereiro de 1888 (Figuras 6 e 8). Esses dados indicam que a "cor" legitimava a permanência de uma cultura análoga à da escravidão nas relações de trabalho, conferindo, ao mesmo tempo, um novo fundamento para as hierarquias sociais. A força da cor enquanto classificação social é sua ambivalência, a capacidade de abrigar significados culturais diversos e inacabados. Nesse contexto, a valorização simbólica dessa antiga nomenclatura de grupos para além do escravista stricto sensu, tal como expresso de modo radical nas teorias raciais do período, está relacionada às reivindicações por novos direitos e status forjadas no processo de emancipação.

Com efeito, a Lei Áurea significou, para muitos negros, a possibilidade de ruptura definitiva com a etiqueta estamental da escravidão nas

40 Uma discussão interessante sobre esse aspecto encontra-se em Frederik Cooper, Thomas C. Holt e Rebecca J. Scott, Além da escravidão: investigações sobre raça, trabalho, cidadania em sociedades pós-emancipação, Rio de Janeiro: Civilização Brasileira, 2005, pp. 54-74. 
relações sociais de produção e na sociabilidade, bem como a superação dos estereótipos cada vez mais racializados que as antigas categorias de cor reforçavam. Assim, a questão da superação dos "preconceitos de raças" foi um tema debatido no contexto da abolição. Conforme celebrou o jornal A Pacotilha, no calor da hora:

O dogma social da igualdade perante a lei e perante a sociedade é de hoje em diante uma realidade, felizmente.

Os resquícios de classes existentes, os preconceitos de raças, e outros tantos prejuízos a que davam lugar as diferenças mantidas pela instituição servil, entre livres e escravos, tombarão esfacelados pelo nivelamento da lei de 13 de Maio! (grifo nosso) ${ }^{41}$

O conteúdo ideológico e simbólico da abolição abrigou significados diversos, como o fim da ordem senhorial, a igualdade de todos os cidadãos perante a lei e, inclusive, a utopia da superação dos "preconceitos de raças" que estigmatizavam a enorme população de negros livres e os últimos cativos do país. Nesse sentido é que os "preconceitos de raça" puderam ser observados, sob o ângulo nativo, enquanto uma persistência de valores e atitudes do passado. A reação senhorial no imediato pós-abolição, como veremos logo abaixo, confere enorme sentido a tais percepções. Entretanto, o fortalecimento e a persistência da cor, como uma das formas dominantes de distinção e formação de grupos sociais, estão ligados à modernização política da sociedade brasileira - as reivindicações por liberdade e igualdade que culminaram no 13 de maio. Essa é uma das razões que fizeram da abolição e dos meses seguintes um ponto de inflexão na luta social pelas fronteiras políticas e culturais da cidadania - problema acirrado, no Maranhão, como vimos, pela insegurança oriunda da crise econômica.

Os jornais da capital maranhense oferecem farto testemunho desses conflitos. Em São Luís, ainda no dia 12 de maio de 1888, alguns indivíduos que participavam de uma passeata para celebrar a aproximação do grande dia, "abusando da hora e do motivo entenderam poder proferir toda sorte de inconveniências, praticando atos reprovados, insultando 
famílias. [...] o desrespeito chegou ao ponto de atirarem pedras, cofos em algumas casas de famílias respeitáveis nas ruas de Santana, Grande e outras, quebrando até vidraças." ${ }^{42}$ Os insultos e agressões investiriam na abolição como motor de uma revolução na ordem social, refletindo impulsos violentos e igualitários de transgressão das regras de fidalguia e convívio que separavam o povo das "famílias respeitáveis", ou oligárquicas. O romance Vencidos e degenerados (1915), do escritor negro maranhense Nascimento Moraes (1882-1958), remonta a alguns conflitos do dia 13 de maio de 1888 :

Momentos depois de proclamada a Lei, começou a divulgar-se a notícia de que uma escrava ao passar pela rua dos Afogados, dera uma bofetada numa senhora que estava à janela. Esta senhora passara por amarga decepção: viu saírem, portas afora, sem um adeus, desvairados, pela comoção da notícia, todos os seus escravos. Diziam os que a conheciam, que era uma mulher má, sedenta de cruéis castigos, e que se apontava, distinta, pela impiedade de sua cólera, pelo arrebatamento do gênio irascível e impensadas ações.

[...]

Provocaram fortes gargalhadas e pilhérias picantes os inesperados cômicos que se deram: cozinheiras que abandonaram os patrões, sem lhes apresentar o jantar; outras que faziam compras e que se foram com dinheiro e balde. E em muitas casas se passaram cenas deprimentes e tristes: escravos dando expansão à raiva e ao ódio cometeram desatinos de toda espécie, quebrando móveis e louças, e mais objetos que se lhes deparavam, e deixavam, a blasfemar, o teto onde tão desgraçados dias viveram, atirando ferinos e brutos impropérios que se iam quebrar, como garrafas e vidros, nas rótulas das janelas, nas portas, e na alma aniquilada dos infelizes ricaços de ontem, que se viram em grande parte, pobres de um dia para outro. 
Não obstante, alguns senhores não ficaram completamente abandonados porque não eram maus. Ao abrirem as portas, ao franquearem a saída aos de há pouco escravos, ofereceram abrigo aos que quisessem continuar na sua companhia. Muitos aceitaram os convites, na maioria os velhos, já inválidos para uma existência laboriosa, e moças que eram crias de muita estima e algum conforto, em geral filhos de escravas com senhores moços. ${ }^{43}$

O trecho do romance não é visto aqui como prova documental, mas por sua qualidade de exagerar, ficcionalmente, o conflito de expectativas geradas com o fim da escravidão. Muitos dos "novos cidadãos" - termo com que os jornais designaram os libertos - acreditaram na abolição como uma grande ruptura histórica. E não só eles. Em suas memórias, Dunshee de Abranches narra que um parente próximo ao poderoso Conselheiro Vieira da Silva caiu morto assim que recebeu a notícia. "Uma velha senhora de engenho, tronco de ilustres políticos conservadores, tentou suicidar-se, ingerindo ervas venenosas." ${ }^{44}$ Por outro lado, alguns senhores não pouparam o uso do chicote para demonstrar que sua autoridade ainda estava de pé, a despeito da abolição. Na vila Rosário, em 15 de maio de 1888, uma mulher foi surrada por se negar ao trabalho.

Ontem o Dr. Mello Rocha mandou surrar a ex-escravizada de nome Maria Urçula. [...] Às cinco horas da tarde procedeu-se o corpo de delito, encontrando-se na ofendida sinais de escoriações, que foram julgados leves! Fez-se auto de perguntas e a ofendida declarou ter sido surrada a mandado do Dr. Mello Rocha, porque não pode ir trabalhar por estar doente. O mesmo Dr. Mello Rocha declarou em um auto assinado por ele, delegado e promotor público, que tinha surrado a sua escrava de nome Maria Urçula, pois não conhecia lei alguma que o impedisse de tal fazer. ${ }^{45}$

43 José do Nascimento Moraes, Vencidos e degenerados: crônica maranhense. São Luís: Tip. Ramos, 1915, pp. 13-14.

44 Abranches, A esfinge, p. 33.

45 Diário do Maranhão, 18 maio 1888, p. 2. 
Se o senhor parece ter se safado, afirmando que desconhecia a lei que libertou seus escravos, sua alegação é contestada pela historiadora Regina Helena Faria, que observa que a denúncia procedeu de vizinhos e que Rosário era suficientemente próxima da capital maranhense para receber a notícia. ${ }^{46}$ Também pesou para a anulação do processo o fato de Maria Urçula haver deposto a favor do ex-senhor, afirmando que seus sofrimentos foram poucos e que costumava ser bem tratada por Mello Rocha. O depoimento sugere intimidação e/ou falta de perspectiva para a liberta, caso rompesse com a tutela senhorial.

Na cidade de São Luís, foram noticiadas denúncias de que alguns senhores insistiam na escravidão, valendo-se de brechas legais para alegar que a Lei Áurea não revogava a obrigação de cumprimento das prestações de serviços pelos adolescentes e crianças alforriadas por efeito da Lei do Ventre Livre (ou Lei Rio Branco), assinada em 28 de setembro de 1871. Argumentavam que as crianças nascidas de "ventre livre" - as chamadas "ingênuas" -, deveriam permanecer sob controle dos senhores de suas mães até os 21 anos.

Um ingênuo que tinha sido dado de aluguel pelo ex-senhor ou ex-senhora de sua mãe, a quem pertenciam seus serviços até a idade de 21 anos, pela lei Rio Branco, querendo retirar-se da casa, em que se achava, para alugar-se noutra, em que os salários the pertencessem, foi coagido por um empregado da companhia de aprendizes marinheiros a voltar para a casa em que sua senhora ou seu senhor o alugara, em seu exclusivo interesse, sob pena de assentar praça naquela companhia, para onde iria irremissivelmente, si ousasse de novo ter procedimento igual ao que tivera.

É o cúmulo da sordidez.

Informa-se-nos também que foram desligados de uma liberta os filhos ingênuos que com ela viviam, e todos os menores de oitos

46 Regina Helena Faria, "Controle social e resistência em tempos de liberdade: os ecos da escravidão", Reunião Regional da SBPC-MA, Educação, Cultura e Ciência para a Cidadania (São Luís, 2004). 
anos, porque ela entendeu, e entendeu bem, que não devia continuar a prestar serviços a quem a libertara com essa condição.

Diz-se-nos que três filhos desta infeliz, menores de sete anos, foram remetidos para Guimarães, ficando um, o mais velho, em casa do manumissor de sua mãe, que clama ter o direito de gozar os serviços dele até completar 21 anos. ${ }^{47}$

O não cumprimento da lei deixava no ar o fantasma da reescravização. A lógica paternalista da manumissão protelou a emancipação e restringiu a cidadania daqueles "libertos", que não eram considerados plenamente livres. As crianças e adolescentes recém libertadas eram, particularmente, intimidadas pelas ameaças de ingresso na Companhia de Aprendizes de Marinheiros do Maranhão, famosa pelos severos castigos e torturas. "Ainda ontem um empregado daquela companhia fez com que um ingênuo voltasse para o domínio da sua senhora - intimando-o de que mandar-lhe-ia sentar praça." ${ }^{48}$

O Club Artístico Abolicionista Maranhense também denunciou a execução de prisões arbitrárias, como a da ex-escrava Candida - antes pertencente a d. Maria José Franco Mattos -, que fora detida sob a acusação de causar distúrbios motivados pelo vício da embriaguez nos festejos de 16 de maio. $\mathrm{O}$ encarceramento teria sido realizado por um "agente da autoridade muito acostumado ao embarque com o aparato de escolta, cordas e ferros, como se deu com Esmeralda, Paulino, Jordão e tantos outros, de que a capital foi testemunha nos tempos idos dos Srs. Cajurubebas." Nesse mesmo dia vieram a público denúncias de reescravização na capital: "consta-nos também que philantropos há que, não sabemos com que direito, ou com que título, conservam reclusos, debaixo de sete chaves, como se costuma dizer, libertos pela lei de 13 de Maio. Dizem-nos que esta gentileza se dá lá pelas bandas do Caminho Grande." ${ }^{50}$

Muito da força e persistência dos valores e práticas escravistas na sociedade maranhense se devem aos pequenos proprietários urbanos.

47 A Pacotilha, 22 maio 1888, p. 3.

48 A Pacotilha, 22 maio 1888, p. 2.

49 A Pacotilha, 22 maio 1888, p. 2.

50 A Pacotilha, 22 maio 1888, p. 3. 
Era gente que não havia sido contemplada pelas grandes fortunas e/ou pelo prestígio político do baronato local, mas estava ávida por distinção social, numa sociedade fortemente regrada por critérios estamentais, como testemunham seus grandes sobrados coloniais, igrejas e azulejos. No romance de Nascimento Moraes é feita uma das observações mais notáveis sobre a capilaridade do escravismo na rede urbana e as reações ao fim do cativeiro na capital do Maranhão:

Mais que os ricos, sofreram, porém, os pobres que tinham escravos. Os pobres presumidos. Faziam economias, com prejuízo da alimentação, e ostentavam pequeno cabedal de negros. Os escravos dos pobres sofriam as mais ridículas e apalhaçadas vexações porque o espírito pequenino dos seus senhores se deliciava em os ocupar a todo instante com as coisas mais insignificantes, bagatelas, que, à vista falta de meios, neles patentes, tomavam aspectos bem deslavados e grotescos.

Pertencer à primeira sociedade era possuir, pelo menos, duas ou três cabeças de negros. Imagina-se facilmente o desconsolo em que ficaram esses pequenos proprietários, quando se viram, num minuto, abandonados pelos escravos que tinham comprado à custa de mil sacrifícios e inúmeras necessidades, aqueles servidores que trabalhavam diariamente à chuva e ao sol expostos, e que lhes garantiam com o produto das energias gastas o pão de cada dia. ${ }^{51}$

Não nos importa aqui o realismo da descrição, mas a ênfase verossímil num tradicionalismo dos setores medianos e baixos da sociedade e na importância da humilhação como estratégia de exibição pública do status. Ao tradicionalismo das pequenas famílias sem linhagem, das beatas e padres, dos pequenos comerciantes e caixeiros portugueses, dos alugadores e contratantes de "moleques", "negrinhas", "criadas mulatinhas" e "pretas" lavadeiras e cozinheiras, também se deve parte substancial da clivagem racial dos direitos conquistados por meio da abolição. 
O medo do retorno à escravidão, ou a condições análogas de sujeição, regulou o estilo de vida organizado pelos libertos no imediato pós-abolição. Assim, em setembro de 1889, Juliana denunciou o ex-proprietário Joaquim Pinto Saldanha por manter sua filha Febronia e mais cinco de seus netos em situação de cativeiro. Conforme o depoimento, "Febronia identifica-se como roceira, morando em um sítio da fazenda Lençóis, onde se ocupa de 'serviços de roça' e 'trabalha para si'. Diz que ‘tem servido' seu senhor [...] mas que ele a paga quando a ocupa e que era muito bem tratada quando escrava." ${ }^{25}$ A despeito da intenção de denúncia de Juliana, tais argumentos levaram à anulação do processo.

A memória oral dos negros maranhenses registra a longevidade da cultura da escravidão nas relações de trabalho, inclusive durante o século XX. O conjunto de depoimentos colhidos em 1982 pelo pesquisador Matthias Röhrig Assunção, na porção oriental do Maranhão - uma região historicamente marcada pela conflagração da Balaiada (1838-1841) - é uma amostra de como as práticas escravistas ultrapassaram em muito o marco legal estabelecido pelo 13 de maio. Para citar um exemplo, o relato de d. Raquel, natural de Magalhães de Almeida, comenta o trabalho exaustivo por tarefa, tipo de serviço que era fonte de graves prejuízos à saúde, que começava de dia e podia varar a noite, com direito a surras:

Eu não alcancei o cativeiro não, mas trabalhava de tarefa. Aí tem muita colega... uma morreu outro dia, mãe desse meu genro aqui, morreu ceguinha. E esta velha que morreu, Ave Maria! gritava: "Me acude, minha gente! Minha cabeça quer rachar". Os olhos dela aquele poço de sangue... As senhoras, aquelas danadas! A gente apanhava... Dava de palmatória. Mas a gente quebrava os bilro, não fazia renda, quebrava os bilro. Mas graças a Deus não tenho as mãos aleijadas. Sou limpa graça a Deus. ${ }^{53}$

Os casos de manutenção de ingênuos cativos e/ou tutelados nas cidades; a manutenção de regras estamentais de conduta frente a trabalhadores "alugados" no serviço doméstico e no comércio; a importância

52 Faria, "Controle social e resistência", p. 1.

53 Mathias Assunção, "Memória do tempo do cativeiro no Maranhão", Tempo, v. 15, n. 29 (2010), p. 85 . 
dos estereótipos associados aos negros e a insistência nos regimes de trabalho compulsório no campo revelam o quão flexíveis eram, na vida prática, as fronteiras entre escravidão e liberdade. Mais do que isso, esses dados apontam que, no pós-abolição, a classificação racial operava transformando práticas associadas ao cativeiro em trabalho para negros e impedindo o pleno reconhecimento social da liberdade conquistada no 13 de maio.

\section{"Nada os satisfaz": 0 "liberto" como problema social}

A invenção do "liberto" como um problema social é outra evidência da complexa relação entre raça e emancipação no pós-abolição. O senso comum, forjado no período, de que os negros, nascidos livres ou não, podiam ser nominados e tratados indiscriminadamente como "libertos" e obrigados a servir, por relação de dependência ou gratidão, àqueles que supostamente os haviam emancipado (os brancos), fazia do estigma do cativeiro uma das marcas da identidade racial. ${ }^{54}$ Um enquadramento que legitimava a persistência da violência física e simbólica, da cultura da escravidão nas relações sociais, contra pessoas tidas como inferiores do ponto de vista cultural e biológico, bem como fonte de tensão e desequilíbrio social, marcou a formação de uma cidadania negra no Brasil moderno.

No debate maranhense sobre a crise econômica das grandes plantações depois do 13 de maio essa questão aparece em cores vivas. Embora as situações narradas ocorressem em diversos lugares do Maranhão, é nos jornais da capital que recebem o tratamento de um problema político mais abrangente. A seguir, analiso missivas e artigos, boa parte dos quais foram escritos a pedidos da Associação Comercial do Maranhão. Sediada em São Luís, tal entidade estimulou políticos e fazendeiros a apresentarem, nos jornais, suas visões sobre a crise econômica do estado. Um dos aspectos centrais do debate seria a insistência no argumento de que, sem a ação repressiva do governo, não seria possível controlar os libertos e outros negros. É o que demonstra uma carta enviada ao Diário do Maranhão:

54 Wlamyra Albuquerque. O jogo da dissimulação: abolição e cidadania negra no Brasil. São Paulo: Companhia das Letras, 2010, pp. 103-104. 
[...] deve logo ser decretada a criação das colônias penitenciárias agrícolas municipais (1,2 ou mais em cada município, conforme sua população) às quais devem ser recolhidos todos os que não forem proprietários, rendeiros, empregados dos estabelecimentos agrícolas, criadores, vaqueiros e não tiverem ofício ou profissão que lhes permita viver honestamente. [...] Serão considerados lavradores os que tiverem uma posse de terra suficiente para manter qualquer lavoura regularmente montada; criadores - de gado vacum ou cavalar - os que possuírem mais de 50 cabeças - de qualquer outra espécie - os que provarem com recibo de estação fiscal que pagam imposto de 100 cabeças anualmente.

Serão igualmente recolhidos a estas colônias todos os que deixarem de pagar a imposição por não frequência dos filhos à escola, e também todos os que forem condenados por pequenos delitos, depois de cumprirem as respectivas sentenças, ficando sem direito ao pecúlio aqueles cujo crime tiver sido furto ou roubo.

Cada uma destas colônias poderá conter até 400 adultos de ambos os sexos $[\ldots]^{55}$

Um estado movido pelo trabalho compulsório de milhares de pessoas concentradas em campos militarizados foi uma das esperanças da elite maranhense para enfrentar a "decadência." Na verdade, a ideia já havia sido posta em prática na província como forma de absorver os migrantes cearenses fugidos da grande seca de 1878. Essas pessoas foram arregimentadas em colônias militares, instaladas em terras devolutas ou territórios quilombolas confiscados. Mas, nesse caso, apesar dos constantes abusos dos militares, a orientação oficial era que esses núcleos se dedicassem à pequena produção independente. No pós-abolição, a Associação Comercial propunha readequar o experimento ao contexto do fim da escravidão. Note-se que, conforme a carta, era possível que um indivíduo que houvesse estado alguma vez na prisão por pequenos delitos jamais fosse reintegrado à sociedade, passando do cárcere diretamente à penitenciária agrícola, sem direito a receber qualquer pecúlio por seu trabalho. 
O desejo de reaprisionar os libertos revela a descrença de alguns ex-senhores na possibilidade de "disciplinar" os trabalhadores através de formas de trabalho não compulsório, dada a enorme quantidade de terras férteis fora do controle do estado e a resistência ao trabalho subordinado depois da abolição. Mais do que um sentimento, o tema "medo" dos libertos nesses escritos é um argumento político com vistas a assegurar interesses materiais e ideais da antiga aristocracia da terra. O problema do "mau uso da liberdade" e do "despreparo cultural" dos libertos para a cidadania foi mobilizado nesse tipo de argumento, sob a justificativa de que o Maranhão - diferentemente dos estados do sul agrário, que haviam sido bafejados pela imigração europeia - estaria sendo obrigado à "substituição do trabalho escravo pelo livre com os próprios elementos da Província." ${ }^{56}$ Esse foi o tema de uma missiva enviada pela Associação Comercial ao Diário do Maranhão por um proprietário de S. Vicente Ferrer:

Analfabeta e sem a menor educação, sem hábito de trabalho, viciosa e malfeitora, [a população livre do campo] pode ser considerada - verdadeiramente selvagem.

Não tem habitação regular, contentando em ter por abrigo uma latada de pindoba na qual não se encontra um único móvel nem utensílio algum; na maior parte destas habitações não se encontra sequer um caldeirão, sendo a comida assada sobre brasas; dormem em miaçabas [sic] ou em jiraus de talos de pindoba; não plantam uma árvore frutífera, não criam ao menos galinhas e nada produzem quer em trabalhos de roça, quer em outro qualquer ramo. A maior parte desta população nada produz absolutamente, e os poucos que são considerados trabalhadores, porque fazem uma pequena roça, não produzem anualmente o valor de $20 \$ 000$ por família de 4, 5 ou mais pessoas aptas para o trabalho.

A colheita anual dessas famílias varia de 2 a 6 arrobas de algodão em caroço; e é tudo quanto fazem! 
Com estes hábitos e costumes, não tendo nada que os prenda ao lugar, vivem em contínuas mudanças, o que fazem sem custo algum porque nada tem a transportar senão a própria pessoa.

É tão grande a indolência que em tempo algum se encontra um alqueire de arroz, farinha, milho, feijão, carrapato [mamona] etc., ainda mesmo em lugar de população crescida.

Ordinariamente agrupam-se em roda das fazendas dos proprietários e tornam-se o maior flagelo, furtando e destruindo os frutos nas roças e até as galinhas nos quintais, e, se os donos se opõem, tomam desforços de toda a natureza, indo até lançar fogo nos canaviais. ${ }^{57}$

O fim da escravidão, o abalo dos padrões de autoridade típicos do cativeiro e a enorme importância econômica dos roceiros livres são descritos e sentidos como a redução do Maranhão a um estado selvagem. Observe-se que, na imaginação econômica senhorial, toda atividade realizada fora dos marcos da grande propriedade não é qualificada como "trabalho produtivo" - daí a afirmação de que "o nosso homem livre é uma entidade que não existe economicamente falando." ${ }^{58}$ Entretanto, se aquela gente livre ameaçava os proprietários era justamente pelo contrário: a emancipação autonomizou a pequena produção, impulsionando o crescimento de roças em terras devolutas, tanto para a própria subsistência, quanto para o comércio - e, nesse sentido, não surpreende a preocupação da Associação Comercial em desmerecer a produção de algodão dos roceiros libertos e livres. Por outro lado, a menção aos "furtos" e "roubos" de frutos e animais e a ausência de caldeirão e outros utensílios nos precários abrigos de madeira, onde viviam temporariamente pessoas em trânsito, sugerem que as migrações constantes, a insegurança e as perseguições marcaram a experiência negra no pós-abolição.

A mobilização de estereótipos que sugeririam uma inconstância desses trabalhadores - como a vadiagem, as volições criminosas, o modo de vida, o tipo de alimentação e a improdutividade - constitui a reação tradicionalista à desorganização da produção e ao estremecimento da

58 Diário do Maranhão, 28 maio 1888, p. 2 
etiqueta senhorial, insinuando a resistência dos ex-senhores frente à necessidade de negociar novas condições de trabalho, no momento em que a desagregação da grande lavoura escravista era inevitável. Entre os "maus hábitos" do trabalhador livre estava o de que este se considerava portador de direitos: "exigem logo o adiantamento dos jornais, alegando que precisam de comprar uma calça ou camisa; os que obtêm o abono nunca mais aparecem para o não pagar e os que não obtêm tomam este pretexto para não ir ao trabalho, porque não podem ir sem roupa para fora de casa." (grifos do autor). ${ }^{59}$ Tudo é descrito como se a violência do Estado e a violência pessoal fossem componentes necessários para a integração social dos libertos ao novo status de cidadãos.

Os proprietários que optaram por meios dissuasórios costumeiros para manter os libertos em suas fazendas mobilizaram o mesmo esquema de percepção racial anterior à Lei Áurea em suas relações com seus trabalhadores. No dia 30 de maio de 1888, o proprietário Carlos Theodoro Gonçalves, residente na comarca de Pindaré, compartilhou, nas páginas de $O$ Paiz, as medidas que implantara para manter os antigos escravos trabalhando na sua lavoura de cana, além de outros planos. A nova organização do trabalho em sua fazenda partia do princípio de que "a indústria agrícola não pode manter-se pagando salário - quando se estorce oprimida por passivos extraordinários e a agonia entre juros galopantes."60 Outro expediente que tornava o pagamento de salários nada recomendável, a seu ver, era que "a educação do escravo entre nós torna-o refratário ao estímulo e o fato de se achar liberto, e vencendo o salário, não são ainda incentivos suficientes para que se esforcem e se empreguem meios de fazer produzir o necessário para o custeio."61 Numa frase: o pagamento de salários, além de prejuízo econômico ao fazendeiro, em nada dignificaria essa qualidade inferior, não educada, de trabalhador.

O senhor Theodoro Gonçalves também condenava o contrato por parcerias, no qual o proprietário obtém dividendos a partir do arrendamento da terra, visto que "esperar que os libertos entre si se associem

59 Diário do Maranhão, 28 maio 1888, p. 2. Grifo nosso.

60 O Paiz, 30 maio 1888, p. 3.

61 O Paiz, 30 maio 1888, p. 3. 
é uma esperança perigosa, infeliz. [...] [S]em que um centro os dirija, e que respeitem e confiem, nada deles se pode e deve esperar - senão crimes e ociosidade." ${ }^{\prime 2}$ Para amealhar o respeito e confiança dos seus antigos escravos, o fazendeiro "achou oportuno" "libertá-los desde logo - sem condição alguma", atitude que recomendava aos colegas de classe, visando firmar, em $1^{\circ}$ de janeiro de 1889 , uma sociedade com todos os libertos que preferissem ficar em sua companhia, pois "o direito de escolha é agradável ao liberto e dele resulta que raros são os que preferem abandonar os seus cômodos e abrigo à incerteza de uma novidade cujos resultados não podem garantir." ${ }^{63}$ Assim, libertar os escravos, "desde logo" ou não, além de estabelecer condições de manter as antigas relações de trabalho, foi uma estratégia senhorial que alimentou, entre os libertos, o medo da reescravização.

De Pindaré veio também a público, na edição do dia 2 de junho de 1888 de $O$ Paiz, a colaboração do senhor P. J., argumentando que as ilusões de que os libertos permaneceriam espontaneamente nas fazendas haviam durado pouco. "O teatro do seu cativeiro afigura-se-lhe um inferno, quer deixá-lo; a sua liberdade não é completa porque não gozou quanto deseja, e por isso a ideia do trabalho por enquanto o horroriza. A desconfiança o persegue, e ele vê no ex-senhor o seu verdugo de ontem e o seu traidor de amanhã. ${ }^{964}$ A memória da violência na escravidão, a vontade de gozar a vida e, sobretudo, a desconfiança de que o ex-senhor transformaria muito pouco as práticas de exploração do trabalho seriam motivos de sobra para que, nessa primeira hora, os libertos tivessem verdadeiro horror a permanecer nas propriedades onde haviam sido cativos. "A ideia do liberto não é garantir sua subsistência, é principalmente isolar-se, viver sobre e para si, dormir e gozar quando entender, sem ter que dar contas, o que não sucede se for associado ou se contrair compromissos com quem quer que seja." ${ }^{15}$ Nesse sentido, embora o autor também considere o salário o meio mais oneroso de recompensar o trabalhador,

\footnotetext{
62 O Paiz, 30 maio 1888, p. 3.

63 O Paiz, 30 maio 1888, p. 3.

$64 O$ Paiz, 2 jun. 1888, p. 2

65 O Paiz, 2 jun. 1888, p. 2.
} 
"deve ser este o meio único de operar a substituição do trabalho na província, sofrendo-se, embora, alguns prejuízos." 6

Além do salário, cujo valor justo calculou em torno de 300 reis diários, mais a comida, P. J. recomendava expressamente aos donos de terras que não coagissem os libertos a permanecer nas fazendas, considerando mais vantajoso estabelecer contratos com trabalhadores de origens diversas, se possível de outras comarcas. Também deveria ser expressamente proibido permitir que as terras fossem invadidas, habitadas ou roçadas por libertos que não fossem assalariados do próprio estabelecimento. Para o fazendeiro, quanto menos laços sociais os libertos tivessem entre si, maior seria a autoridade do proprietário sobre eles.

O notável interesse de alguns ex-senhores por decifrar o significado da liberdade para seus trabalhadores, como indicam as preleções acima sobre "o direito de escolha" e "a ideia do liberto", revela que o 13 de maio se transformara num aporte político importante para que os egressos do cativeiro pudessem fazer de suas expectativas de emancipação individual e coletiva um componente ideológico de peso na organização de sua própria vida. Fato é que, se levarmos a sério as queixas dos proprietários, a abolição definitiva da escravidão os pressionava para que os arranjos possíveis no mundo do trabalho e da sociabilidade estivessem em conformidade com os novos tempos:

Nada os satisfaz, nem há conselho e admoestações que lhes aproveite. Não respeitam nem sustentam os contratos que fazem com os proprietários e todos os dias os alteram. Recusaram as ofertas que a maior parte dos fazendeiros lhes fizeram da participação a meio nas colheitas, inclusive a pendente: recusam aforamentos de terra que se lhes propõe, e nunca dizem o que querem, contentando-se em responder nós não queremos a tudo quanto se lhes propõe. Muitas vezes amanhecem as fazendas desertas e só depois de 3 a 4 dias é que começam a chegar dos passeios, sempre ébrios, um a um. Voga entre os libertos que a rainha os libertou não é para se sujeitarem mais, e, como as palavras exprimem o pensamento, deve-se concluir que estão no propósito de não mais 
se dedicar ao trabalho. De sua parte dizem os livres que agora como precisamos deles para recolher nossas colheitas havemos de lhes pagar salários dobrados se quizermos o seu trabalho. Que desgraça! Estamos inteiramente perdidos!!! (grifos do autor) ${ }^{67}$

O trecho acima pertence a um abaixo-assinado, enviado à Sociedade Auxiliadora da Lavoura e da Indústria com 260 assinaturas de latifundiários maranhenses ligados aos dois partidos políticos do Império - uma subscrição "sem distinção de cor política", liberal ou conservadora, como frisa o fim do documento. Para este grupo de proprietários autoproclamados "desgraçados" e "perdidos", seus infortúnios resultavam da estreita margem de negociação das relações de trabalho com seus ex-escravos, estimulados estes por suas próprias "visões da liberdade". ${ }^{68}$ Note-se que parecia ser praxe não oferecer salários aos ex-escravos: quando o abaixo-assinado se refere a eles, cita apenas o "insulto" da recusa ao aforamento e à meação. Por sua parte, o "desaforo" dos trabalhadores livres, provavelmente roceiros, jornaleiros e peões, tradicionalmente "alugados" para a colheita, era a exigência de salários dobrados.

Um trecho emblemático do documento é quando os fazendeiros tentam explicar as razões políticas que movem a insubordinação dos ex-escravos: "Voga entre os libertos que a rainha os libertou não é para se sujeitarem mais, e, como as palavras exprimem o pensamento, deve-se concluir que estão no propósito de não mais se dedicar ao trabalho." Mais uma vez, quero destacar a naturalização do conceito de "trabalho", entendido aí exclusivamente na forma da grande lavoura, bem como a centralidade da sujeição como categoria nativa de entendimento ${ }^{69} \mathrm{O}$ termo servia como sinônimo de escravidão, mas se manteve corrente no pós-abolição, pois caracterizava mais propriamente a relação de dependência do que o confinamento forçado da mão de obra, tradicionalmente descrito na memória oral dos negros maranhenses como "cativeiro."

67 O Paiz, 13 ago. 1888, p. 3. Grifo nosso.

68 Sidney Chalhoub, Visões da liberdade, São Paulo: Companhia das Letras, 1990.

69 As ambiguidades dessa representação coletiva foram examinadas pioneiramente em: Afrânio Garcia Jr., "Libertos e sujeitos; sobre a transição para trabalhadores livres do Nordeste". Revista Brasileira de Ciências Sociais, v. 3, n. 7 (1988), pp. 1-35. Sobre o mesmo tema, cf. Walter Fraga Filho, Encruzilhadas da liberdade: histórias de escravos e libertos na Bahia (1870-1910), Campinas: Ed. Unicamp, 2006, p. 260. 
A sujeição é um padrão de relações sociais ligadas à experiência da escravidão, implicando na não diferenciação entre o tempo do trabalho e do lazer; na obediência inconteste ao senhor; na legitimidade do uso de violência a mando do senhor; na sonegação de salários; na disponibilidade permanente para o patrão; e na dependência econômica da grande lavoura. Enfim, o termo "sujeição" envolve muito daquilo que materializava o cativeiro, do ponto de vista dos negros.

Se acreditarmos nos argumentos apresentados na petição dos fazendeiros, um dos elementos mais interessantes ali sugeridos é a relação dos libertos com a princesa Isabel. A figura de "rainha" surge como representação dos recentes direitos conquistados, como instância de autoridade capaz de questionar o arbítrio do paternalismo senhorial e as práticas cotidianas assemelhadas ao cativeiro. Aliás, esse reconhecimento da presença amorfa do cativeiro na etiqueta das relações sociais pode ser entrevista em alguns silêncios e recusas: "nunca dizem o que querem, contentando-se em responder nós não queremos a tudo quanto se lhes propõe." O "não quero" dos libertos, buscando maximizar suas alternativas de autonomia pessoal e coletiva no campo e nas cidades e assim fazer valer as conquistas do 13 de maio, estimulou, entre as elites, um conjunto de representações raciais sobre aqueles sujeitos como inconstantes, ingratos, preguiçosos e, não raro, criminosos. Um aporte simbólico para a invenção de um "problema negro" no pós-abolição. ${ }^{70}$

\section{Considerações finais}

Nestas últimas linhas, vale enfatizar que muito do esforço em caracterizar algumas singularidades do caso maranhense nas páginas anteriores teve o objetivo de persuadir o leitor para o fato de que qualquer interpretação sobre a construção social da raça como uma das formas dominantes de categorização e fabricação de grupos no Brasil precisa levar em conta as especificidades regionais. Do contrário, corre-se o risco de generalizar aquelas histórias locais, geralmente referenciadas nos principais centros

70 Cf. Guerreiro Ramos, Introdução crítica à sociologia brasileira, Rio de Janeiro: Ed. Uerj, 1995, p. 165. 
políticos, econômicos e culturais do país, mas que foram eleitas e simbolizadas, pelo senso comum douto, como "nacionais".

Na região estudada, a existência de uma enorme população livre de pessoas nominadas como "caboclos", "pretos", "pardos", "mulatos", "cafuzos", desde meados do século XIX, tornou cada vez mais importante a mobilização da etiqueta social e simbólica da escravidão, em especial da velha nomenclatura das cores, para subjugar e controlar homens e mulheres que viviam fora do cativeiro. O uso dessas categorizações de grupo contra negros e mestiços livres alterou e ampliou os significados culturais da cor, intensificando a racialização dos critérios de distinção social na sociedade maranhense. A crise do sistema agroexportador do algodão, do arroz e da cana, a propalada inviabilidade da imigração europeia, bem como a posição periférica ocupada pela elite maranhense no Estado nacional acirraram ainda mais esse processo e evidenciaram a debilidade do controle senhorial para regular inteiramente a formação dos "novos" grupos sociais no pós-abolição, seja no campo ou na cidade. A invenção "liberto" como um problema social condensava valores e atitudes que insistiam no passado, bem como davam lugar a um novo campo simbólico de legitimidade para a dominação racial. Por outro lado, as particularidades da região permitem observar um elemento estrutural da configuração do racismo moderno no Brasil: a proeminência da cultura e da política - isto é, um conjunto de tensões cotidianas em torno de disputas por status e direitos, aliada à concentração do poder político oligárquico - enquanto fator a orientar o estabelecimento das fronteiras raciais no espaço da cidadania.

Recebido em 11/10/2018 e aprovado em 8/10/2019 


\title{
Resumo
}

A emancipação dos últimos escravos afro-brasileiros foi sancionada numa só penada, mas chegou de diversas maneiras ao norte e ao sul do país: conforme o desenvolvimento da economia e sua função no sistema agroexportador; a preponderância ou não da população negra e mestiça nas províncias, cidades, comarcas e povoados; a importância do trabalhador livre nas diferentes agriculturas escravistas; a presença do incentivo estatal ou privado em favor da imigração estrangeira europeia ou asiática; o atraso ou modernização do sistema produtivo da grande lavoura; a força política do latifúndio no pós-abolição; e a relevância dos estados e regiões na condução da política brasileira. Este artigo visa caracterizar o imediato pós-abolição maranhense tendo em vista a luta social em torno da liberdade, a legitimação de estratégias de domínio senhorial e a categorização racial enquanto critério de subordinação de grupos. Utilizo para esse fim dados primários coligidos nos jornais maranhenses e outros documentos de época correlacionando-os às descobertas da antropologia social do campesinato, da historiografia do pós-abolição e da sociologia das relações raciais, para caracterizar a construção da cidadania negra na periferia do norte agrário brasileiro.

Palavras-chave: raça - pós-abolição - racialização - reescravização - Maranhão.

\begin{abstract}
The emancipation of the last African-Brazilian slaves was sanctioned at a fell swoop, though its arrangements varied in many ways from Brazilian North to South, depending on factors such as: the development of the economy and its role in agroexport system; the preponderance of the black and mestizo population in the provinces, cities, counties and towns; the importance of free workers in different slave agricultures; the presence of the State or the private incentive for the European and Asian immigration; the delay or modernization of the plantation system; the plantation's political force in the post-abolition period; and the significance of states in Brazilian politics. This article aims to characterize the immediate post-abolition period in Maranhão, Brazil, considering the social struggle over freedom, the legitimacy of the master's domain strategies and the racial categorization as a criterium for group subordination. I use primary data collected in local newspapers and other historical documents and highlight the recent work on social anthropology of the peasantry, on post-abolition historiography, and sociology of race relations to characterize the construction of black citizenship at the periphery of the Brazilian agrarian North.
\end{abstract}

Keywords: race - post-abolition - racialization - re-enslavement - Maranhão. 